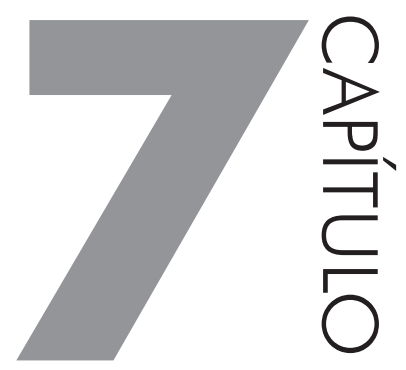

\title{
A DESCOBERTA DE UMA NOVA POSSIBILIDADE DE ATUAÇÃO PROFISSIONAL
}

\section{ITALO WELKE DE ANDRADE}

\section{SÍNTESE DO PERCURSO}

Apesar das minhas ressalvas com a modalidade de ensino a distância (devido a experiências ruins como discente), optei por investir tempo e me permitir entender como funciona o trabalho de um Tutor e como consequência a dinâmica e todo o processo desta modalidade de ensino ainda tão estigmatizada por uma suposta falta de qualidade.

As primeiras semanas do curso foram muito ricas, sobretudo devido aos conteúdos compartilhados. Os vídeos e textos sugeridos foram muito bem escolhidos e me permitiram construir uma nova perspectiva sobre o ensinar, compartilhar saberes, a postura e posição de um educador-mediador. É importante ressaltar que eu nunca havia tido contado com conteúdo pedagógico, com as diretrizes do ser educador.

No entanto, não posso romantizar este percurso. Houve momentos de dificuldade a partir do módulo cinco: falta de motivação e foco para dar prosseguimento ao curso. Escrever este artigo está sendo desafiador. Decidi assistir novamente o vídeo da aula inaugural e em algum momento foi apresentado por Otacilio Santana (Tutor do curso) os quatro tipos de motivação: por existência, por vocação, pelo exemplo e por cooperação. 
A motivação por existência reapareceu em mim (preciso do certificado para ampliar minhas chances de inserção no mercado de trabalho como Tutor) e é a responsável pela minha ação de escrever este artigo. Estou em um momento decisivo na minha vida. Um momento de grandes mudanças. Sem dúvidas este curso é uma das pontes para o meu sonho.

Além disso, a prática da Tutoria foi muito rica. Pude participar da estruturação da disciplina, da apresentação da ementa e das atividades programadas, e da orientação e avaliação final dos trabalhos. Também criei grupos de comunicação e compartilhamento de informação no Whatsapp, Gmail e Facebook e disponibilizei meus contatos telefônicos, de e-mail e redes sociais para eventuais necessidades.

\section{FATO MARCANTE}

A Teoria da Zona de Desenvolvimento Proximal (ZDP) de Vygotsky era totalmente desconhecida por mim. Fiquei encantado pelas ideias e contribuições do autor e entusiasmado para colocá-las em prática. Muito embora alguns conceitos desta teoria façam parte do nosso dia a dia e da prática profissional mesmo não sabendo nomeá-las adequadamente.

Em conversa com a professora titular da disciplina, decidimos inovar e ouvir os alunos para montarmos a programação da disciplina. Questionamos as principais dificuldades dos alunos quanto à formação acadêmica, as perspectivas de inserção no mercado de trabalho, aos formatos de aula, a forma de avaliação etc. Montamos a disciplina focando a prática profissional, conforme sugestões dos alunos e consentimento meu e da professora titular.

No início e final da disciplina houve momentos programados de discussão sobre autodisciplina e automotivação com os alunos. Eu expus minha trajetória de vida, as dificuldades, minhas conquistas pessoais e acadêmicas. Para mim, minha própria trajetória é um fator que me motiva a ir ainda mais longe.

A maioria dos alunos da disciplina é oriunda de famílias humildes, são os primeiros a ingressarem na Universidade e depositam o sonho da mudança de vida no curso de graduação. É um percurso que se conecta diretamente com o meu. Ter tido essa troca foi muito importante para todos nós. Alguns alunos relataram que o fato de eu ter uma história de vida similar a deles gerou uma zona de empatia forte. O fato de eu ser egresso do mesmo curso de graduação que eles e aluno de mestrado no mesmo departamento foram pontos, citados por eles, que criaram uma zona mais estreita de proximidade. $\mathrm{O}$ fato de eu saber das dificuldades enfrentadas por eles devido às desilusões e críticas em relação ao curso facilitou a comunicação e propiciou um contato e experiência muito ricos. 


\section{MÉTODO POTENTE UTILIZADO NO PROCESSO DE ENSINO- APRENDIZAGEM}

Considero pertinente o método de avaliação dos trabalhos adotada na disciplina. Após as aulas teóricas os grupos foram divididos em grupos e ficaram responsáveis por analisar empresas reais a fim de identificar problemas críticos na gestão da informação dessas empresas e propor planos de ações para aperfeiçoar o processo.

Após a apresentação dos trabalhos (que foi dividido em etapas) os alunos apresentavam os resultados preliminares e os demais grupos contribuíam com sugestões de melhorias, novas abordagens, críticas etc.

Observou-se um melhor aproveitamento dos conteúdos, quando comparado com turmas anteriores. O desenvolvimento do conhecimento coletivo através do debate, da autocrítica e da avaliação dos trabalhos de outros grupos mostrou-se um eficiente.

\section{LIMITAÇÕES}

As principais limitações observadas foram: a) baixa adesão as orientações e aos debates online, que de acordo com Vergara (2007) se deve a questões culturais do povo brasileiro, que prefere encontros presenciais; dificuldade de acesso as tecnologias de informação e comunicação e a internet, alguns alunos relataram a falta de acesso a esses meios.

\section{PERSPECTIVA DA TUTORIA COMO PROJETO EDUCACIONAL}

A tutoria propicia um ambiente adequado para a criação de projetos educacionais a partir da troca de informações, do aprendizado colaborativo, da solução de problemas em equipe, da falta de hierarquia, dentre outras características oriundas da configuração em rede.

O método utilizado por este pesquisador no processo de ensino-aprendizagem reforça esta perspectiva: a solução de problemas reais de forma colaborativa e por meio dos atores envolvidos no processo.

\section{AGRADECIMENTOS}

Gostaria de agradecer a professora $\mathrm{Dr}^{\mathrm{a}}$ Nadi Helena Presser por ter me aceito como Tutor da disciplina Informação para Negócios e pelas orientações e feedbacks sobre a prática profissional do educador. 


\section{REFERÊNCIAS}

VERGARA, S. C. Estreitando relacionamentos na educação a distância. Cad. EBAPE. BR, v. 5, n. spe, p. 01-08, 2007. DOI: 10.1590/S1679-39512007000500010 